\title{
Spinal cord cysticercosis: neurosurgical aspects
}

\author{
Benedito Oscar Colli, M.D., Ph.D., Marcelo Moraes Valença, M.D., Ph.D., \\ Carlos Gilberto Carlotti, Jr., M.D., Ph.D., Hélio Rubens Machado, M.D., Ph.D., \\ and Jỗo Alberto Assirati, JR., M.D.

\begin{abstract}
Division of Neurosurgery, Department of Surgery, Ribeirão Preto Medical School, University of São Paulo; Ribeirão Preto; São Paulo; and Division of Neurology and Neurosurgery, Department of Neuropsychiatry, Federal University of Pernambuco, Recife, Pernambuco, Brazil
\end{abstract}

\begin{abstract}
Object. The authors report their experience in the treatment of 12 symptomatic patients with intradural spinal neurocysticercosis.

Methods. The mean age of the 12 patients was 33 years. There were eight female and four male patients. Cysticercosis was present in association with hydrocephalus in nine cases. In nine of 12 patients the spinal lesion was confined to the thoracic or lumbar spinal cord, and in three the cysticerci occupied the cervical region. In all patients with hydrocephalus nerve root symptoms developed seven to 48 months later (mean $27.6 \pm 15.5$ months). In one patient hydrocephalus was absent, but he presented with cysticercal meningitis 24 months before spinal cord compression developed. Presenting symptoms suggesting spinal cysticercosis included muscular weakness (67\%), pain $(67 \%)$, and sphincter disturbance $(25 \%)$. Neurological examination demonstrated a motor deficit in nine patients, sensory deficit in four, and radicular pain in three. The prognosis was worse in patients with moderate-to-severe arachnoiditis and spinal cord compression compared with those with isolated nerve roots involvement in whom outcome was favorable. Ten patients underwent laminectomy, after which neurological status improved in $44 \%$, remained unchanged in $33 \%$, or worsened in $22.2 \%$.

Conclusions. The authors discuss their findings in these cases. Additionally they briefly review the literature, pathophysiology, and therapeutic and/or surgical strategies involved in this disease.
\end{abstract}

\section{KeY WordS - cysticercosis - spinal cord • spinal cord - Taenia solium • hydrocephalus}

Human cysticercosis, one of the most prevalent forms of parasitosis of the CNS, is caused by Cysticercus cellulosae, the metacestode stage of Taenia solium. We estimate that at least one third of the world population lives in an area endemic for T. solium and cysticercosis and that an estimated 50 million people are infected, causing approximately 50,000 deaths annually. Emigration of infected persons from endemic areas, such as Latin and South America, Africa, India, and Asia has resulted in the increasing incidence of NCC in developed countries. ${ }^{4}$ This increase can be inferred from a number of series of patients with NCC published in North America ${ }^{29,30}$ and Europe ${ }^{42}$ Therefore, the taeniasis/cysticercosis poses a major public health problem, no longer restricted to developing countries, but now in developed countries as well. In some of the endemic regions the prevalence of the parasitosis is very high, affecting 3 to $10 \%$ of the populations. ${ }^{10,20,37}$

Because the majority of patients with NCC are asymptomatic or have minor neurological complaints (for example, headache and vertigo), it is difficult to determine if the

Abbreviations used in this paper: $\mathrm{CNS}=$ central nervous system; $\mathrm{CSF}=$ cerebrospinal fluid; $\mathrm{CT}=$ computerized tomography; $\mathrm{MR}=$ magnetic resonance; $\mathrm{NCC}=$ neurocysticercosis . symptoms are related to CNS cysticercosis or if the finding of one or more cysticerci in the neural parenchyma is an incidental finding on neuroimaging in individuals with unrelated sickness..$^{10,20,31,37}$

Epileptic seizures, meningitis, intracranial hypertension, hydrocephalus, and focal neurological deficits are the main neurological manifestations of NCC. The neurological symptoms will depend on variables ${ }^{20}$ such as the topography of the cysticerci in the CNS parenchyma, CSF space, or both; number of cysticerci; the natural progression of the cysticercus from the early phase of active live form (vesicular cyst), colloidal stage (degenerating cyst), granular stage to the calcified nodular inactive phase; immunoallergic parasite-host interaction; ${ }^{43}$ sex and age of the patient; and among others putative factors (that is, genetic susceptibility ${ }^{25}$ strain of T. solium, ${ }^{16}$ and tropical climate ${ }^{20}$ ).

In some patients, for unknown reasons, $\mathrm{NCC}$ develops a progressive, often recurrent, chronic form of the disease, which, if not promptly treated, frequently results in death. It is estimated that up to $25 \%$ of the patients develop a severe malignant form of the disease, with life-threatening cerebral complications. Thus, parenchymal cysts usually have a better prognosis with regard to extraparenchymal NCC (that is, ventricular, spinal, and subarachnoid varieties). ${ }^{5}$ 
Interestingly, the parasitic involvement of the spinal cord and its nerve roots is a relatively rare event. ${ }^{6,8,9,13,20 \text {, }}$ 26,33,36,37 Intradural spinal cysticercosis can be subdivided in leptomeningeal (subarachnoid) or intramedullary forms (parenchymal), the former being the most prevalent type of spinal parasitic infestation. In contrast to CNS lesions caused by the parasite Schistosoma mansoni, ${ }^{41}$ in which the spinal cord is the principal site of damage, intramedullary involvement in cysticercosis is seldom observed, accounting for fewer than $20 \%$ of the intradural spinal cases. ${ }^{9}$ Intramedullary spinal cord cysticerci, however, are being increasingly recognized by MR imaging. ${ }^{33}$ Epidural cysts are rare. ${ }^{26}$ In addition to other stigmata of cerebral cysticercosis, in patients with the spinal form clinical and radiological features may be similar to intra- or extramedullary neoplastic mass lesions. Flaccid or spastic paresis, sensory deficits, sphincter disorders, radiating pain, and pyramidal signs are the most commonly observed clinical manifestations of spinal cysticercosis. ${ }^{13}$

Sotelo, et al., ${ }^{37}$ have reported their experience with 753 patients with NCC studied at the Institute National de Neurología y Neurociruría de México; they assessed clinical features, CT scans, and CSF findings. They noted that both sexes are affected equally; $26 \%$ of their patients were asymptomatic and the diagnosis was made only after performing $\mathrm{CT}$ or CSF studies. In their series, spinal cysts occurred rarely $(0.7 \%)$, compared with arachnoiditis in $48.2 \%$, and hydrocephalus (29.5\%). Moreover, parenchymal calcifications were present in $57.6 \%$ and active-form parenchymal cysts in $13.2 \%$ of the individuals. Analyzing neurosurgical aspects in approximately 1000 cases of NCC, Escobedo ${ }^{20}$ reported that the parasites lodged in brain parenchyma in approximately $60 \%$, in the subarachnoid space in approximately $40 \%$, in the ventricular cavities in nearly $10 \%$, and in the spine in approximately $1 \%$ of the cases, with mixed forms in more than half of the patients.

In the present study we report our experience in the treatment of 12 symptomatic patients with intradural spinal NCC. A brief review of the literature, pathophysiology, and therapeutic and/or surgical strategies is discussed. We also propose a prophylactic approach of routine priorities as an attempt to eradicate parasitosis.

\section{CLINICAL MATERIAL AND METHODS}

Twelve $(7.4 \%)$ of 163 patients with NCC-related complications who underwent neurosurgical procedures at the Division of Neurosurgery of the Hospital das Clínicas, Ribeirão Preto Medical School, University of São Paulo between January 1980 and December 2001 were the subjects of this study. Spinal cysticercosis was present in all patients. They underwent myelography, CT myelography, or MR imaging of the whole spinal cord, as well as CT scanning or MR imaging of the skull. Some of the patients were included in a previous study. ${ }^{11}$

The diagnosis of NCC was based on clinical and epidemiological findings, CSF reactions (complement fixation reaction, indirect immunofluorescence test, and enzymelinked immunosorbent assay, neuroimaging, pathological examination, and surgical aspects of the lesions. ${ }^{18}$ Data are shown as the mean \pm standard deviation unless otherwise indicated. Laminectomy was performed in 10 patients. Patients with intracranial hypertension-related hydrocephalus underwent placement of a ventriculoperitoneal shunt and several patients with cysticercal meningitis also received chronic corticoisteroid therapy. In two patients in whom no surgery was performed glucocorticoid therapy was administered. Anticysticercal drugs were not used to treat spinal cysticercosis.

In the evaluation of surgical or medical treatment, we classified the results as: 1) improved, when there was a significant improvement of the clinical neurological signs; 2) unchanged, when the same signs persisted; and 3) worsened, when the treatment resulted in worsening of the clinical status or in patient death.

\section{RESULTS}

Table 1 provides a summary of the clinical, surgical, and neuroimaging features found in each of the 12 patients with spinal NCC. There were eight female and four male patients (female/male ratio 2:1). The mean patient age was 33 years (range 15-51 years); there was no statistical difference in age between sexes (males $30 \pm 14$ years of age; females $34 \pm 12$ years of age; $p>0.05$ [Student t-test]). Spinal cysticercosis of the leptomeningeal form was present in all patients, in nine of whom it was associated with hydrocephalus. In nine $(75 \%)$ of 12 patients the spinal lesions were confined to the thoracic and/or lumbar spinal cord; in $25 \%$ of the patients the cysticerci occupied the cervical regions (Fig. 1). In three patients the cauda equina was compressed. Figure 2 shows a CT myelography scan demonstrating the presence of hypodense rounded and irregular gap of filling around the spinal cord, suggesting cysticercosis, which was confirmed during surgery.

In all patients with hydrocephalus, symptoms secondary to spinal cord and/or nerve root compression appeared 7 to 48 months later (mean 27.6 \pm 15.5 months; median 24 months). In the patient in Case 11 hydrocephalus was absent, but he presented with cysticercal meningitis 24 months before developing chest pain radiating to the lower limbs. Each of the patients in this study had experienced neurological dysfunction related to either spinal cord or nerve damage. Most presented with symptoms corresponding to intracranial hypertension syndrome, such as headache, vomiting, transient visual loss, ataxic gait, diplopia, and papilledema at the time hypertensive hydrocephalus or meningitis was diagnosed. Presenting symptoms suggesting spinal cysticercosis included muscular weakness in eight (67\%), pain in eight (67\%), and sphincter disturbances in three (25\%). Neurological examination disclosed motor deficit in nine patients $(75 \%)$, sensory deficits in four (33\%), and radicular pain in three $(25 \%)$ that was triggered by passive straight-leg raising (Lasègue sign). Most of the patients presented with arachnoiditis $(90 \%)$ or the intradural racemose cysts $(80 \%)$. Typically the prognosis was worse in patients with intense-to-moderate arachnoiditis and spinal cord compression (Cases 1, $3,5,10$, and 12) and in the two patients (Cases 4 and 9) in whom neuroimaging documented intense arachnoiditis (not surgically treated), compared with those with isolated nerve root involvement and/or with discrete inflammatory 


\section{Spinal cord cysticercosis: neurosurgical aspects}

TABLE 1

Summary of pre- and posttreatment characteristics in 12 patients with $N C C^{*}$

\begin{tabular}{|c|c|c|c|c|c|c|c|c|c|}
\hline $\begin{array}{l}\text { Case } \\
\text { No. }\end{array}$ & $\begin{array}{l}\text { Age, (yrs) } \\
\text { Sex }\end{array}$ & $\begin{array}{l}\text { Spinal } \\
\text { Level }\end{array}$ & $\begin{array}{l}\text { Hydro- } \\
\text { ceph- } \\
\text { alus }\end{array}$ & $\begin{array}{c}\text { Inter- } \\
\text { val } \dagger\end{array}$ & $\begin{array}{l}\text { Presenting } \\
\text { History }\end{array}$ & $\begin{array}{l}\text { Neurological } \\
\text { Status }\end{array}$ & Treatment & Op Findings & $\begin{array}{l}\text { Posttreatment } \\
\text { Course }\end{array}$ \\
\hline 1 & $15, \mathrm{~F}$ & T-9 & yes & 21 & $\begin{array}{l}\text { decreased lower- } \\
\text { limb strength }\end{array}$ & leg paraparesis & $\begin{array}{l}\text { T7-12 lami- } \\
\text { nectomy }\end{array}$ & $\begin{array}{l}\text { intense arachnoid- } \\
\text { itis }\end{array}$ & $\begin{array}{l}\text { progressive worsening w/ } \\
\text { paraplegia \& incontin- } \\
\text { ent bladder; died of in- } \\
\text { creased ICP } 2 \text { yrs postop }\end{array}$ \\
\hline 2 & $23, \mathrm{~F}$ & $\mathrm{~T} 2-\mathrm{L} 1$ & yes & 7 & $\begin{array}{l}\text { chest/lumbar pain } \\
\text { radiating to lower } \\
\text { limbs \& decreased } \\
\text { lower-limb } \\
\text { strength for } 4 \text { mos }\end{array}$ & $\begin{array}{l}\text { leg paraparesis; } \\
\text { tactile/painful } \\
\text { hypesthesia w/ } \\
\text { T-3 level }\end{array}$ & $\begin{array}{l}\text { L1-4 lami- } \\
\text { nectomy }\end{array}$ & $\begin{array}{l}\text { excised active \& } \\
\text { degenerated sub- } \\
\text { arachnoid race- } \\
\text { mose cysts; mod- } \\
\text { erate arachnoiditis }\end{array}$ & $\begin{array}{l}\text { decreased pain; persis- } \\
\text { tence of decreased } \\
\text { muscle strength in lt leg }\end{array}$ \\
\hline 3 & $24, \mathrm{~F}$ & $\mathrm{~L} 2-5$ & no & NA & $\begin{array}{l}\text { sudden lumbar pain } \\
\text { radiating to rt leg } \\
\text { for } 8 \mathrm{mos}\end{array}$ & $\begin{array}{l}\text { tactile/painful } \\
\text { hypesthesia in } \\
\text { L3-S1 on the lt } \\
\text { \& in L5-S1 on } \\
\text { on the rt; bilat } \\
\text { Lasègue sign }\end{array}$ & $\begin{array}{l}\text { L2-5 lami- } \\
\text { nectomy }\end{array}$ & $\begin{array}{l}\text { excised subarach- } \\
\text { noid racemose } \\
\text { cysts; moderate } \\
\text { arachnoiditis }\end{array}$ & $\begin{array}{l}\text { temporary remission of } \\
\text { pain; wide lumbar filling } \\
\text { gap (arachnoiditis) on } \\
\text { myelography } 3 \text { yrs } \\
\text { postop }\end{array}$ \\
\hline 4 & $36, \mathrm{~F}$ & T11-L5 & yes & 48 & $\begin{array}{l}\text { difficulty walking } \\
\text { \& sphincter } \\
\text { changes for } 5 \text { mos }\end{array}$ & $\begin{array}{l}\text { leg paraparesis, } \\
\text { walking w/ } \\
\text { support }\end{array}$ & clinical & NA & $\begin{array}{l}\text { slow \& progressive wors- } \\
\text { ening; walking w/ sup- } \\
\text { port; developed neuro- } \\
\text { genic bladder }\end{array}$ \\
\hline 5 & $40, \mathrm{~F}$ & C5-6 & yes & 12 & $\begin{array}{l}\text { progressive de- } \\
\text { creased extremity } \\
\text { strength \& diffi- } \\
\text { culty urinating } \\
\text { for } 4 \text { mos }\end{array}$ & $\begin{array}{l}\text { spastic quadri- } \\
\text { paresis \& urine } \\
\text { retention; con- } \\
\text { fined to bed }\end{array}$ & $\begin{array}{l}\text { C4-7 lami- } \\
\text { nectomy }\end{array}$ & $\begin{array}{l}\text { intense arachnoid- } \\
\text { itis }\end{array}$ & $\begin{array}{l}\text { discrete improvement of } \\
\text { motor deficit }\end{array}$ \\
\hline 6 & $43, \mathrm{~F}$ & $\begin{array}{l}\text { cauda } \\
\text { equina }\end{array}$ & yes & 24 & $\begin{array}{l}\text { lumbar pain radiat- } \\
\text { ing to rt leg } \\
\text { (L5-S1) }\end{array}$ & $\begin{array}{l}\text { deficit of dorsal } \\
\text { flexion of rt foot; } \\
\text { hypalgesia on lat } \\
\text { surface of leg \& } \\
\text { of the rt foot }\end{array}$ & $\begin{array}{l}\text { L3-5 lami- } \\
\text { nectomy }\end{array}$ & $\begin{array}{l}\text { excised racemose } \\
\text { cysts of cauda } \\
\text { equina; discrete } \\
\text { arachnoiditis }\end{array}$ & complete relief of pain \\
\hline 7 & $46, \mathrm{~F}$ & $\mathrm{~T} 1-2$ & yes & 44 & $\begin{array}{l}\text { progressive de- } \\
\text { creased lower- } \\
\text { limb strength } \\
\text { for several mos }\end{array}$ & $\begin{array}{l}\text { universal hypes- } \\
\text { thesia w/ leg } \\
\text { paraparesis }\end{array}$ & $\begin{array}{l}\text { T1-4 lami- } \\
\text { nectomy }\end{array}$ & $\begin{array}{l}\text { excised subarach- } \\
\text { noid degenerated } \\
\text { racemose cysts }\end{array}$ & lost to follow up \\
\hline 8 & $47, \mathrm{~F}$ & T9-L1 & yes & 48 & $\begin{array}{l}\text { lumbar pain radiat- } \\
\text { ing to rt leg; de- } \\
\text { creased lower-limb } \\
\text { strength \& sphincter } \\
\text { changes for } 3 \text { mos }\end{array}$ & leg paraparesis & $\begin{array}{l}\text { T12-L2 lami- } \\
\text { nectomy }\end{array}$ & $\begin{array}{l}\text { excised racemose } \\
\text { cysts of cauda } \\
\text { equina; discrete } \\
\text { arachnoiditis }\end{array}$ & $\begin{array}{l}\text { lumbar pain remained; } \\
\text { lower-limb strength } \\
\text { improved; sphincter } \\
\text { disorder improved }\end{array}$ \\
\hline 9 & $22, \mathrm{M}$ & $\mathrm{C} 12-\mathrm{T} 1$ & yes & 12 & $\begin{array}{l}\text { lumbar pain radiat- } \\
\text { ing to lower limbs } \\
\& \text { decreased lower- } \\
\text { limb strength for } \\
15 \text { mos }\end{array}$ & leg paraparesis & clinical & NA & $\begin{array}{l}\text { unchanged; died of in- } \\
\text { creased ICP } 3 \text { years } \\
\text { postop }\end{array}$ \\
\hline 10 & $24, \mathrm{M}$ & $\begin{array}{l}\text { thoraco- } \\
\text { lumbar }\end{array}$ & no & $24+$ & $\begin{array}{l}\text { chest pain radiating } \\
\text { to lower legs }\end{array}$ & normal & $\begin{array}{l}\text { T8-L2 lami- } \\
\text { nectomy }\end{array}$ & $\begin{array}{l}\text { excised subarach- } \\
\text { noid racemose } \\
\text { cysts; moderated } \\
\text { arachnoiditis }\end{array}$ & $\begin{array}{l}\text { progressive worsening, } \\
\text { development of para- } \\
\text { paresis \& sphincter dis- } \\
\text { orders }\end{array}$ \\
\hline 11 & $24, \mathrm{M}$ & $\begin{array}{l}\text { L3-4, } \\
\text { S-1 }\end{array}$ & yes & 36 & $\begin{array}{l}\text { lumbar pain radiat- } \\
\text { ing to lt leg } \\
\text { (L5-S1) }\end{array}$ & lt Lasègue sign & $\begin{array}{l}\text { L4-5 lami- } \\
\text { nectomy }\end{array}$ & $\begin{array}{l}\text { excised subarach- } \\
\text { noid racemose } \\
\text { cysts; moderate } \\
\text { arachnoiditis }\end{array}$ & $\begin{array}{l}\text { partial decreased pain; } \\
\text { arachnoiditis at op level } \\
\text { on CT myelography }\end{array}$ \\
\hline 12 & $51, \mathrm{M}$ & $\mathrm{C} 3-7$ & no & NA & $\begin{array}{l}\text { lumbar pain \& low- } \\
\text { er-limb paresthesia } \\
\text { for } 10 \text { mos, associ- } \\
\text { ated w/ progressive } \\
\text { motor deficit that } \\
\text { started } 6 \text { mos later }\end{array}$ & $\begin{array}{l}\text { spastic quadri- } \\
\text { paresis }\end{array}$ & $\begin{array}{l}\text { C3-7 lami- } \\
\text { nectomy }\end{array}$ & $\begin{array}{l}\text { excised viable \& } \\
\text { degenerated race- } \\
\text { mose cysts adher- } \\
\text { ent to cervical } \\
\text { cord; moderate } \\
\text { arachnoiditis }\end{array}$ & $\begin{array}{l}\text { persisting motor deficit } \\
\text { \& pain }\end{array}$ \\
\hline
\end{tabular}

* $\mathrm{ICP}=$ intracranial pressure; $\mathrm{NA}=$ not applicable.

$\dagger$ Interval $=$ interval between hydrocephalus and compression (mos).

† Postmeningitis.

elements (Cases 2, 6, and 8), in whom outcome was favorable. The patient in Case 7 was lost to follow up. Considering the other 11 patients pretreatment spinal neuro- logical deficits improved in four, were unchanged in four, and worsened in three.

The intraoperative photograph in Fig. 3 illustrates the 


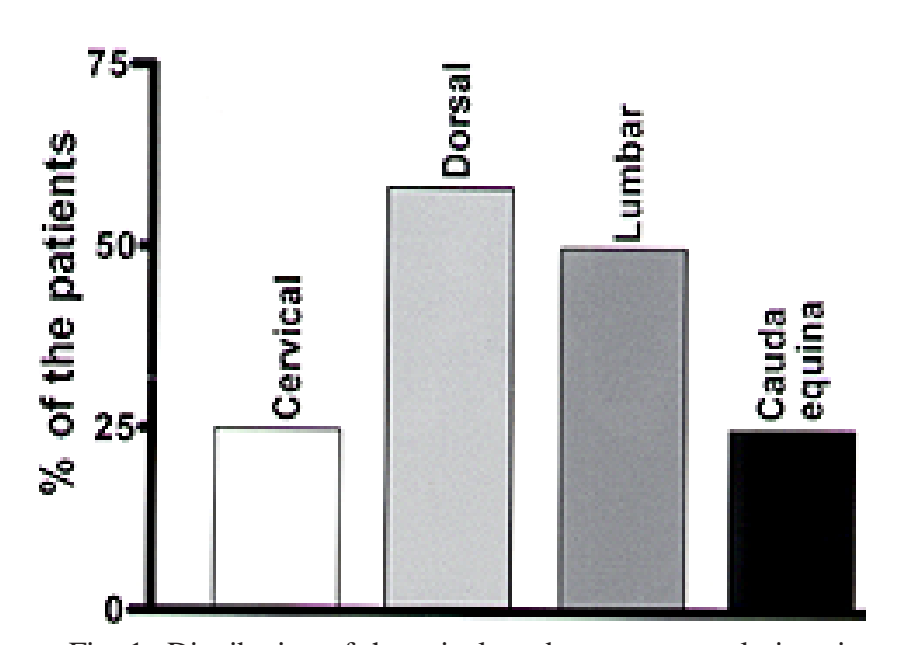

Fig. 1. Distribution of the spinal cord or nerve root lesions in the 12 patients with leptomeningeal spinal cysticercosis. Dorsal = thoracic.

surgical exposure of the spinal cord, demonstrating the presence of several cysticerci in the subarachnoid space. After laminectomy neurological clinical status improved, continued unchanged, or worsened in 44.4, 33.3, and $22.2 \%$ of the patients (nine cases), respectively.

\section{DISCUSSION}

In our patients with spinal cysticercosis neurological symptoms seemed to follow a temporal pattern. Initially the clinical picture usually reflects states of recurrent meningitis in which intracranial hypertension may eventually be preceded by seizures months or years earlier. Hydrocephalus may be diagnosed during an episode of meningitis or a few months later. Interestingly, spinal cord involvement typically appears a few months or years after the development of hydrocephalus and/or episodes of cysticercosis-related meningitis. Obviously, there are exceptions. For example, in the present series of patients one fourth experienced isolated spinal cord symptoms.

In contrast to data reported by Sotelo, et al., ${ }^{37}$ two thirds of our patients were female, suggesting that sex of the host might influence the severity of the neurological deficit. In view of that, during experimental infection, female mice are naturally more susceptible to neurological deficit than males. Gonadectomy equalizes the susceptibility demonstrated between sexes. In addition, 17- $\beta$ estradiol, testosterone, and progesterone did not influence in vitro cysticercus reproduction or growth. Thus, gonadal or sexsteroid effects on susceptibility to cysticercosis seems to be mediated via the immune system rather than a direct action upon the parasites. ${ }^{7,28,40}$ Interestingly, the frequently administered antiepileptic drugs (in patients with NCC), such as carbamazepine and phenytoin, can also alter immune function ${ }^{2,3}$ and, therefore, could affect susceptibility to parasitic infestation.

Several classifications for CNS cysticercosis have been elaborated on the basis of topography, pathophysiology, clinical forms, and neuroimaging aspects of the evolutionary phases of the cysticerci. In our hospital ${ }^{38} \mathrm{NCC}$ was the admitting diagnosis in $7.3 \%$ of patients with neurological

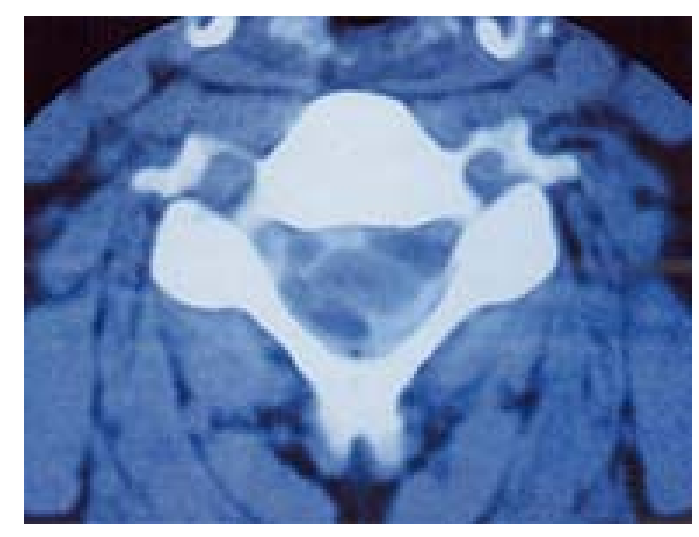

Fig. 2. A CT myelography scan revealing hypodense rounded and irregular gap of filling around the spinal cord, suggesting cysticercosis, which was confirmed during surgery.

disorders and accounted for the diagnosis in $2.7 \%$ of all outpatients. The epileptic form was the more prevalent (64.8\%), followed by the hypertensive form (35.6\%), and the meningitic form (29\%). In $5.8 \%$ of the patients with intracranial hypertension the disease was identified as the pseudotumoral form. ${ }^{14}$

Neurocysticercosis may also be associated with inflammatory cerebral aneurysm and subarachnoid hemorrhage, ${ }^{27}$ temporal lobe epilepsy, ${ }^{31}$ psychiatric manifestations, ${ }^{24}$ and stroke. Recently, a link between NCC and oncogenesis has been postulated. ${ }^{17}$ In this regard, one of our patients, during the evolution of cysticercal disease, developed a cerebellar medulloblastoma (unpublished data).

There are several possible routes by which the parasite reaches the spinal cord parenchyma or CSF. 1) One such route is the hemopoietic venous route, through retrograde blood flow via the inner vertebral venous plexus and the intervertebral veins. ${ }^{36}$ 2) A second possibility is the ventriculoependymal route; ${ }^{9}$ during intraventricular hypertension the ependymal canal would dilate, allowing the cysticercus to migrate from the fourth cerebral ventricle into the spinal cord. Additionally, the ependymal canal is usually open until the 12th year of age in human or even continuing as such in older ages in some individuals, providing the small embryos a natural pathway into the spinal

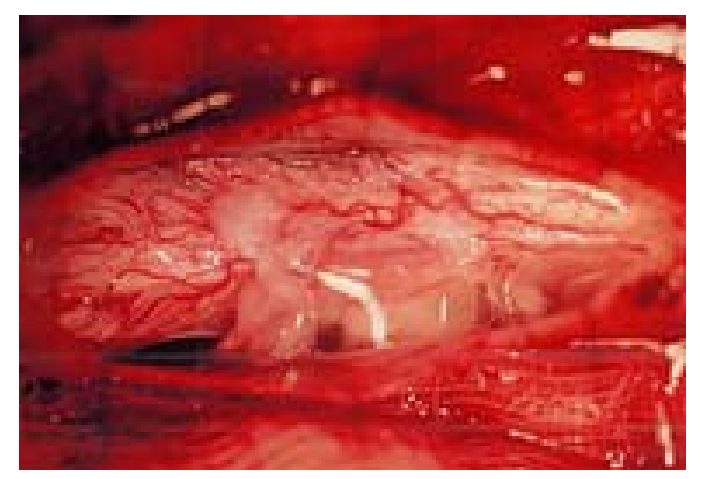

Fig. 3. Intraoperative photograph of the spinal cord demonstrating the presence of several cysticerci in the subarachnoid space. 
cord, before they transform into the 5- to 18-mm cysticerci. 3) A third possible route is subarachnoid, followed by the transpial migration into the spinal cord, a phenomenon that would explain the intramedullary form (although it is unlikely, if at all possible). 4) Lastly, although also unlikely, continuity from the intestinal mucosae to the intradural space may allow the parasites to pass throughout several organic tissue layers, without use of the bloodstream pathway.

The distribution of parenchymal cysticercosis seems to be proportional to the tissue mass that is relative to both brain and spinal cord subdivisions of the CNS or the amount of blood flow/mass of tissue. Despite the fact that the human brain makes up only $2 \%$ of total body weight, it receives 15 to $20 \%$ of cardiac output. The macro- and microvessels of the cerebrovascular network in adult human brain occupy 25 to $30 \%$ of the total brain volume. ${ }^{45}$ This fact may explain why the CNS is the organ of the body where cysticerci are more frequently located (that is, in approximately $60 \%$ of the cases).

Because the cysticerci in nine of the patients in our series were found in an extramedullary location (with a latent period after cerebral cysticercosis), we assume that they migrated via a subarachnoid route, where their movement would be assisted by gravity.

If we consider a hemopoietic arterial route was used by the embryos, which were liberated from eggs $(30-35 \mathrm{~mm}$ in diameter) in the intestine, we must suppose that the parasites are able to pass through the pulmonary circulatory system and into the left side of the heart. Once in the aorta and carotid and vertebral circulations, the tendency of cardiac embolus of parasites is to be confined by one of the microscopic blood vessels of either the parenchyma or the choroid plexus. Our hypothesis is that those embryos that reached the capillaries of the choroid plexus are those that will be present at the intraventricular and subarachnoid CSF compartment. Regarding the latter assumptions, first, the cysticerci would develop in the ventricular system, and some of them would then migrate throughout the foramina of Magendie (medially) and Luschka (laterally), becoming positioned in one of the basal CSF cisterns. Alternatively, the embryos may also enter the CSF via blood vessels present in the pia mater and subependymal region. In the cerebral ventricular system, cysticerci are most commonly found in the fourth ventricle followed by the third ventricle and then lateral ventricles. The effect of gravity could without difficulty explain this fact. If this were true we would expect a higher incidence of NCC to be documented in the spinal canal. Only in a small number of the patients, however, are the cysticerci found below the cisterna magna; in our study in only $7.4 \%$ of the patients with a more severe form of the neuroparasitosis (those treated surgically) did the cysticerci remain within the spinal canal. This incidence would likely be much lower if we were to consider the entire population of patients with neuroparasitosis.

We propose the following hypothesis to account for the low incidence of spinal cysts: of a "sieve effect" may act at the transition level between intracranial and intraspinal subarachnoid spaces. The majority of the cysticerci are larger in size than the subarachnoid space at the cervical level.
The action of the $T$. solium embryos appears to be tropic, as they move toward the intracranial space. This may be explained by an evolutionarily view in which both the natural protection provided by the skull and the relative isolation afforded by the blood-brain barrier from the immunological system ensure the survival of the species. In this light, cysticerci might live as long as 10 years in the human CNS. ${ }^{13}$

Another question is why spinal cord involvement occurs late in the disease course. Indeed, in nine of our 12 patients hydrocephalus developed prior to the spinal cordassociated symptoms. In view of this, four possibilities can be posed: 1) later migration of a cyst formerly located at an intracranial cistern; 2) new parasite infestation; 3) transformation of a once small asymptomatic cyst into a large or racemose form of cysticercosis; or 4) immunoallergic or inflammatory changes occurring after the death of the cysticercus, leading to angiitis, ischemia, and compression of the spinal cord.

Similarly, hydrocephalus may be explained by the presence of cysticerci within the ventricular system, arachnoiditis causing obstruction of the ventricles outlets (isolated ventricle), or of the subarachnoid natural CSF pathways. ${ }^{12,13,15}$ Additionally, hydrocephalus may also be due to extramedullary tumors in which there is CSF flow obstruction at any level of the spinal canal, ${ }^{22}$ particularly in the upper cervical region. Increases in CSF-containing protein levels or inflammation can cause impairment in the CSF absorption as well.

The treatment can be divided into two parts: first, curative treatment of the patient and, second, strategic practices to prevent reinfestation and/or the dissemination of the parasitosis.

Immediate control of the direct causes of the neurological deficit-that is, spinal cord compression, inflammation, intracranial hypertension, CSF pathway obstruction-by undertaking surgery, antiinflammatory drug therapy, or anticysticidol drug treatment, must be kept in mind.

Anticysticidal drugs such as albendazole or praziquantel have been used to treat viable parenchymal cysticerci. ${ }^{39}$ The best treatment - surgical or medical - in patients with giant, intraventricular, or subarachnoid forms of NCC remains unknown. ${ }^{1,5,19,32,34,35}$ Surgical treatment, with excision of the cysticerci after laminectomy, is still indicated in cases of spinal cord or radicular compression by free cysts. In symptomatic patients with intramedullary cysts, surgery is commonly indicated for decompression of the spinal cord as well as to clarify diagnosis. In most cases, cyst resection is technically simple ${ }^{6}$ because the lesions typically adhere to the parenchyma, even when in the degenerative stage. Degenerating intramedullary cysts, however, may present with adhesion to nervous tissue and especially to vessels, making the resection complicated. ${ }^{8}$ Thus, the use of albendazole for viable intramedullary or even subarachnoid cysts would very probably enhance the inflammatory reaction around the cysticerci during its degeneration and could result in neurological worsening.

The management of patients with spinal NCC includes treatment of symptoms (antiepileptic drugs, drugs to combat spasticity) and physiotherapeutic/nursing care to manage bladder problems and paraplegic patients. In addition, as discussed previously, corticosteroid agents may also be 
used to control inflammatory reaction to the cysticercus or its toxins, such as that occurring during episodes of cysticercal meningitis.

The presence of postoperative inflammation and arachnoiditis may be the result of cyst rupture, possibly due to manipulation during surgery. This complication is minimized by provision of saline irrigation during the cyst removal, as well as perioperative use of corticosteroids. ${ }^{12}$

Several conditions and practices are suggested in managing neuroparasitosis: 1) good hygienic habits and adequate sanitary infrastructure (as a historical example, at the beginning of 20th century the improvement of sanitary infrastructure practically eliminated T. solium in Europe. $\left.{ }^{44}\right)$; 2) community health education concerning the importance of human and porcine cysticercosis and their neurological consequences; 3 ) avoid the contact of human feces with the intermediate host (pig); and 4) treatment and prevention of taeniasis (a] identifying and treating individuals with the intestinal form of the parasitosis, $b$ ] cooking pork for at least 5 minutes at $65^{\circ} \mathrm{C}$, and c] freezing pork for at least 12 hours at $-20^{\circ} \mathrm{C} .{ }^{21}$

Mass anticysticidal treatment either in human or in swine populations, meant to treat possible cases of taeniosis to eliminate the source of tapeworm infection in humans, seems to be useful. ${ }^{23}$ Because of its impracticality, however, it is considered more adequate to provide treatment to eliminate tapeworms only in those people previously identified as infected or those at high risk of being carriers. Because of this, we should make every effort to identify individuals with the intestinal form of infection, particularly in our patients because as many as $25 \%$ of those with NCC also carry the intestinal form of the $T$. solium (self-infestation). Thus, treatment and prevention of human intestinal infection are mandatory. An alternative approach for the control of taeniasis and cysticercosis due to T. solium is the use of vaccines in pigs. ${ }^{23}$

Several other parasitic diseases may involve the CNS such as schistosomiasis, malaria, amebiasis, coenurosis, echinococcosis, paragonimiasis, trichinosis, filariasis, angiostrongylosis, gnathostomiasis, and Toxocara canis encephalitis. ${ }^{20}$ There was an alarming increase of the latter during the last two decades, as a result of acquired immune deficiency syndrome.

The incidence of cysticercosis is increasing worldwide, and the morbidity and mortality rates remain high despite the use of modern neurosurgical and radiological technology. The best alternative is the preventive treatment of parasitosis.

In conclusion, spinal leptomeningeal cysticercosis is a relatively rare late-onset complication of NCC, usually affecting patients with a history of hydrocephalus. Racemose cysticercosis and/or arachnoiditis are the predominant features of the disease affecting the spine. The prognosis is worsen in patients with spinal cord involvement who present with significant arachnoiditis. In a patient with peripheral nervous system compression (that is, cauda equina compression) or mild form of arachnoiditis, a favorable outcome is expected.

\section{References}

1. Agapejev S, Da Silva MD, Ueda AK: Severe forms of NCC: treatment with albendazole. Arq Neuropsiquiatr 54:82-93, 1996

2. Andrade-Mena CE, Sardo-Olmedo JA, Ramirez-Lizardo EJ: Effects of carbamazepine on murine humoral and cellular immune responses. Epilepsia 35:205-208, 1994

3. Andrade-Mena CE, Sardo-Olmedo JA, Ramirez-Lizardo EJ: Effects of phenytoin administration on murine immune function. J Neuroimmunol 50:3-7, 1994

4. Apuzzo MLJ, Dobkin WR, Zee CS, et al: Surgical considerations in treatment of intraventricular cysticercosis. An analysis of 45 cases. J Neurosurg 60:400-407, 1984

5. Bandres JC, White AC Jr, Samo T, et al: Extraparenchymal NCC: report of five cases and review of management. Clin Infect Dis 15:799-811, 1992

6. Barini O: Cisticerco macrocístico intramedular. Extirpação cirúrgica. Arq Neuropsiquiatr 12:264-266, 1954

7. Bojalil R, Terrazas LI, Govezensky T, et al: Thymus-related cellular immune mechanisms in sex-associated resistance to experimental murine cysticercosis (Taenia crassiceps). J Parasitol 79:384-389, 1993

8. Cabieses F, Vallenas M, Landa R: Cysticercosis of the spinal cord. J Neurosurg 16:337-341, 1959

9. Canelas HM, Ricciardi-Cruz O, Escalante OAD: Cysticercosis of the nervous system: less frequent clinical forms. Arq Neuropsiquiatr 21:77-86, 1963

10. Chimelli L, Lovalho AF, Takayanagui OM: [Neurocysticercosis: contribution of autopsies in the consolidation of mandatory notification in Ribeirão Preto-SP, Brazil.] Arq Neuropsiquiatr 56:577-584, 1998 (Por)

11. Colli BO, Assirati Junior JA, Machado HR, et al: Cysticercosis of the central nervous system. II. Spinal cysticercosis. Arq Neuropsiquiatr 52:187-199, 1994

12. Colli BO, Martelli N, Assirati JA Jr, et al: Results of surgical treatment of NCC in 69 cases. J Neurosurg 65:309-315, 1986

13. Colli BO, Martelli N, Assirati JA Jr, et al: Surgical treatment of cysticercosis of the central nervous system. Neurosurg Quart 5:34-54, 1995

14. Colli BO, Martelli N, Assirati Junior JA, et al: Cysticercosis of the central nervous system. I. Surgical treatment of cerebral cysticercosis: a 23 years experience in the Hospital das Clinicas of Ribeirao Preto Medical School. Arq Neuropsiquiatr 52: 166-186, 1994

15. Colli BO, Pereira CU, Assirati Junior JA, et al: Isolated fourth ventricle in neurocysticercosis: pathophysiology, diagnosis, and treatment. Surg Neurol 39:305-310, 1993

16. Correa D, Laclette JP, Rodriguez-del-Rosal E, et al: Heterogeneity of Taenia solium cysticerci obtained from different naturally infected pigs. J Parasitol 73:443-445, 1987

17. Del Brutto OH, Dolezal M, Castillo PR, et al: Neurocysticercosis and oncogenesis. Arch Med Res 31:151-155, 2000

18. Del Brutto OH, Rajshekhar V, White AC Jr, et al: Proposed diagnostic criteria for neurocysticercosis. Neurology 57: 177-183, 2001

19. Del Brutto OH, Sotelo J, Aguirre R, et al: Albendazole therapy for giant subarachnoid cysticerci. Arch Neurol 49:535-538, 1992

20. Escobedo F: Neurosurgical aspects of neurocysticercosis, in Schmidek H, Sweet W (eds): Operative Neurosurgical Techniques: Indications, Methods, and Results, ed 3. Philadelphia: WB Saunders, 1995, pp 1705-1715

21. Fan PC, Ma YX, Kuo CH, et al: Survival of Taenia solium cysticerci in carcasses of pigs kept at 4 C. J Parasitol 84:174-175, 1998

22. Feldmann E, Bromfield E, Navia B, et al: Hydrocephalic dementia and spinal cord tumor. Report of a case and review of the literature. Arch Neurol 43:714-718, 1986

23. Flisser A, Lightowlers MW: Vaccination against Taenia solium cysticercosis. Mem Inst Oswaldo Cruz 96:353-356, 2001

24. Forlenza OV, Filho AH, Nobrega JP, et al: Psychiatric manifes- 
tations of neurocysticercosis: a study of 38 patients from a neurology clinic in Brazil. J Neurol Neurosurg Psychiatry 62: 612-616, 1997

25. Fragoso G, Lamoyi E, Mellor A, et al: Genetic control of susceptibility to Taenia crassiceps cysticercosis. Parasitology 112: 119-124, 1996

26. Gallani NR, Zambelli HJ, Roth-Vargas AA, et al: [Spinal cord cysticercosis: report of 2 cases, review of the literature, and comments on its pathology.] Arq Neuropsiquiatr 50:343-350, 1992 (Por)

27. Huang PP, Choudhri HF, Jallo G, et al: Inflammatory aneurysm and neurocysticercosis: further evidence for a causal relationship? Case report. Neurosurgery 47:466-468, 2000

28. Huerta L, Terrazas LI, Sciutto E, et al: Immunological mediation of gonadal effects on experimental murine cysticercosis caused by Taenia crassiceps metacestodes. J Parasitol 78: 471-476, 1992

29. Kelley R, Duong DH, Locke GE: Characteristics of ventricular shunt malfunctions among patients with neurocysticercosis. Neurosurgery 50:757-762, 2002

30. Leblanc R, Knowles KF, Melanson D, et al: Neurocysticercosis: surgical and medical management with praziquantel. Neurosurgery 18:419-427, 1986

31. Leite JP, Terra-Bustamante VC, Fernandes RM, et al: Calcified neurocysticercotic lesions and postsurgery seizure control in temporal lobe epilepsy. Neurology 55:1485-1491, 2000

32. Noboa C: Albendazole therapy for giant subarachnoid cysticerci. Arch Neurol 50:347-348, 1993

33. Parmar H, Shah J, Patwardhan V, et al: MR imaging in intramedullary cysticercosis. Neuroradiology 43:961-967, 2001

34. Proaño JV, Madrazo I, Avelar F, et al: Medical treatment for neurocysticercosis characterized by giant subarachnoid cysts. $\mathbf{N}$ Engl J Med 345:879-885, 2001

35. Proaño JV, Madrazo I, García L, et al: Albendazole and praziquantel treatment in neurocysticercosis of the fourth ventricle. J Neurosurg 87:29-33, 1997

36. Rossitti SL, Roth-Vargas AA, Moreira AR, et al: Cisticer- cose espinhal leptomeningeal pura. Arq Neuropsiquiatr 48: 366-370, 1990

37. Sotelo J, Guerrero V, Rubio F: Neurocysticercosis: a new classification based on active and inactive forms. A study of 753 cases. Arch Intern Med 145:442-445, 1985

38. Takayanagui OM, Jardim E: Aspectos clínicos da neurocisticercose: análise de 500 casos. Arq Neuropsiquiatr 41:50-63, 1983

39. Takayanagui OM, Jardim E: Therapy for neurocysticercosis. Comparison between albendazole and praziquantel. Arch Neurol 49:290-294, 1992

40. Terrazas LI, Bojalil R, Govezensky T, et al: A role for 17-betaestradiol in immunoendocrine regulation of murine cysticercosis (Taenia crassiceps). J Parasitol 80:563-568, 1994

41. Valença MM: Critérios diagnósticos da esquistossomose mansônica meningomielorradicular. Arq Neuropsiquiatr 60: 181-182, 2002

42. Wadley JP, Shakir RA, Rice Edwards JM: Experience with neurocysticercosis in the UK: correct diagnosis and neurosurgical management on the small enhancing brain lesion. Br J Neurosurg 14:211-218, 2000

43. White AC Jr, Tato P, Molinari JL: Host-parasite interactions in Taenia solium cysticercosis. Infect Agents Dis 1:185-193, 1992

44. Zeitz M, Schneider T, Voigtel: JMM, past and present. J Mol Med 79:417-418, 2001

45. Zlokovic BV, Apuzzo MLJ: Strategies to circumvent vascular barriers of the central nervous system. Neurosurgery 43: 877-878, 1998

Manuscript received April 15, 2002.

Accepted in final form June 5, 2002

Address reprint requests to: Benedito Oscar Colli, M.D., Ph.D., Departamento de Cirurgia, Hospital das Clínicas, Faculdade de Medicina de Ribeirão Preto, USP, Campus Universitário, 14048900 Ribeirão Preto, São Paulo, Brazil. 